\title{
Front Matter: Volume 9531
}

, "Front Matter: Volume 9531," Proc. SPIE 9531, Biophotonics South America, 953101 (1 July 2015); doi: 10.1117/12.2203172

SPIE. Event: SPIE Biophotonics South America, 2015, Rio de Janeiro, Brazil 


\title{
Biophotonics South America
}

\author{
Cristina Kurachi \\ Katarina Svanberg \\ Bruce J. Tromberg \\ Vanderlei Salvador Bagnato \\ Editors
}

\section{3-25 May 2015}

Rio de Janeiro, Brazil

Sponsored by

SPIE

Cosponsored by

International Photodynamic Association

FAPESP - The São Paulo Research Foundation (Brazil)

Conselho Nacional de Desenvolvimento Cientifico e Tecnológico (Brazil)

Published by

SPIE 
The papers included in this volume were part of the technical conference cited on the cover and title page. Papers were selected and subject to review by the editors and conference program committee. Some conference presentations may not be available for publication. The papers published in these proceedings reflect the work and thoughts of the authors and are published herein as submitted. The publisher is not responsible for the validity of the information or for any outcomes resulting from reliance thereon.

Please use the following format to cite material from this book:

Author(s), "Title of Paper," in Biophotonics South America, edited by Cristina Kurachi, Katarina Svanberg, Bruce J. Tromberg, Vanderlei Salvador Bagnato, Proceedings of SPIE Vol. 9531 (SPIE, Bellingham, WA, 2015) Article CID Number.

ISSN: 1605-7422

ISBN: 9781628416961

Published by

SPIE

P.O. Box 10, Bellingham, Washington 98227-0010 USA

Telephone +1 3606763290 (Pacific Time) · Fax +1 3606471445

SPIE.org

Copyright (C) 2015, Society of Photo-Optical Instrumentation Engineers.

Copying of material in this book for internal or personal use, or for the internal or personal use of specific clients, beyond the fair use provisions granted by the U.S. Copyright Law is authorized by SPIE subject to payment of copying fees. The Transactional Reporting Service base fee for this volume is $\$ 18.00$ per article (or portion thereof), which should be paid directly to the Copyright Clearance Center (CCC), 222 Rosewood Drive, Danvers, MA 01923. Payment may also be made electronically through CCC Online at copyright.com. Other copying for republication, resale, advertising or promotion, or any form of systematic or multiple reproduction of any material in this book is prohibited except with permission in writing from the publisher. The CCC fee code is $1605-7422 / 15 / \$ 18.00$.

Printed in the United States of America.

Publication of record for individual papers is online in the SPIE Digital Library.

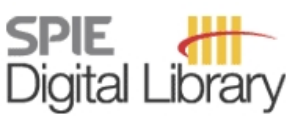

SPIEDigitalLibrary.org

Paper Numbering: Proceedings of SPIE follow an e-First publication model, with papers published first online and then in print. Papers are published as they are submitted and meet publication criteria. A unique citation identifier (CID) number is assigned to each article at the time of the first publication. Utilization of CIDs allows articles to be fully citable as soon as they are published online, and connects the same identifier to all online, print, and electronic versions of the publication. SPIE uses a six-digit CID article numbering system in which:

- The first four digits correspond to the SPIE volume number.

- The last two digits indicate publication order within the volume using a Base 36 numbering

system employing both numerals and letters. These two-number sets start with 00, 01, 02, 03, 04, $05,06,07,08,09,0 A, 0 B \ldots$. OZ, followed by 10-1Z, 20-2Z, etc.

The CID Number appears on each page of the manuscript. The complete citation is used on the first page, and an abbreviated version on subsequent pages. 


\title{
Contents
}

\author{
ix Authors \\ xiii Conference Committees \\ $\mathrm{xV}$ Introduction
}

\section{SESSION 1 TISSUE MICROSCOPY}

953107 Full-field optical coherence tomography for tissue imaging (Invited Paper) [9531-1]

9531 OA Delivery of ultrashort spatially focused pulses through a multimode fiber for two photon endoscopic imaging [9531-4]

9531 OB Image correlation based method for the analysis of collagen fibers patterns [9531-5]

9531 OC Tumor tissue characterization using polarization-sensitive second harmonic generation microscopy [9531-6]

\section{SESSION 2 NANOBIOPHOTONICS}

9531 OE EGFR-specific nanoprobe biodistribution in mouse models [9531-10]

\section{SESSION 3 TISSUE OPTICS}

9531 OL Oil-based gel phantom for ultrasound and optical imaging [9531-18]

$9531 \mathrm{OM}$ Estimating retinal vascular permeability using the adiabatic approximation to the tissue homogeneity model with fluorescein videoangiography [9531-19]

9531 OP Evaluation of the variable depth resolution of active dynamic thermography on human skin [9531-22]

\section{SESSION 4 PHOTODIAGNOSIS}

9531 OS Combined phosphorescence-holographic approach for singlet oxygen detection in biological media [9531-27]

\section{SESSION 5 CLINICAL APPLICATIONS}

9531 OW Evaluation of eye tissue elasticity by means of sound propagation speed measuring in vivo [9531-32] 


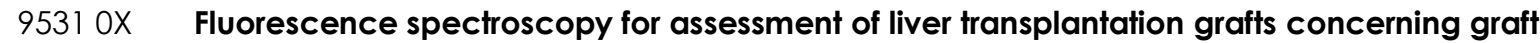
viability and patient survival [9531-33]

SESSION 6 INSTRUMENTATION

953111 Fluorescence multi-scale endoscopy and its applications in the study and diagnosis of gastro-intestinal diseases: set-up design and software implementation [9531-164]

953114 A compact multi-wavelength optoacoustic system based on high-power diode lasers for characterization of double-walled carbon nanotubes (DWCNTs) for biomedical applications [9531-39]

953115 Development of an in situ controllable polymerization tool and process for hydrogel used to replace nucleus pulposus [9531-41]

\section{SESSION 7 SPECTROSCOPY I}

953116 Fabry-Perot micro-structured polymer optical fibre sensors for opto-acoustic endoscopy (Invited Paper) [9531-43]

953117 Preparation of HIV monoclonal antibody-conjugated pulchellin in order to study its intracellular trafficking pathway in HIV-infected cells by confocal microscopy. [9531-44]

953118 In vitro evaluation of ionizing radiation effects in bone tissue by FIR spectroscopy [9531-45]

9531 1A A simple dental caries detection system using full spectrum of laser-induced fluorescence [9531-24]

\section{SESSION 8 TISSUE OPTICS II}

$9531 \mathrm{lF}$ Infrared irradiation of skin for the development of non-invasive health monitoring technologies [9531-51]

$9531 \mathrm{lH}$ 3D Monte Carlo radiation transfer modelling of photodynamic therapy [9531-54]

$953111 \quad$ Monolayer to MTS: using SEM, HIM, TEM and SERS to compare morphology, nanosensor uptake and redox potential in MCF7 cells (Invited Paper) [9531-56]

$95311 \mathrm{~J}$ Biochemical changes in cutaneous squamous cell carcinoma submitted to PDT using ATRFTIR spectroscopy [9531-57]

9531 1L Applications of Raman spectroscopy in life science [9531-59] 
9531 IP Innovative parameters obtained for digital analysis of microscopic images to evaluate in vitro hemorheological action of anesthetics [9531-23]

$95311 Q$ Comparative clinical study using laser and LED-therapy for orofacial pain relief: dentin hypersensitivity and cervicogenic headache [9531-63]

9531 IR Study of the scattering of the light in aqueous samples collagen in the presence of nanoparticles and curcuma pigment [9531-64]

9531 is Methylene blue photodynamic therapy in rats' wound healing: 21 days follow-up [9531-65]

9531 IT Clinical study on orofacial photonic hydration using phototherapy and biomaterials [9531-66]

9531 IV Optical properties of human radicular dentin: ATR-FIIR characterization and dentine tubule direction influence on radicular post adhesion [9531-68]

9531 IW Blue LED irradiation to hydration of skin [9531-69]

953121 Single LED-based device to perform widefield fluorescence imaging and photodynamic therapy [9531-75]

953122 Asymmetry and irregularity border as discrimination factor between melanocytic lesions [9531-76]

953125 Raman spectroscopic analysis of oral squamous cell carcinoma and oral dysplasia in the highwavenumber region [9531-79]

953129 Attenuation coefficient of the light in skin of BALB/C and C57BL/6 mice [9531-83]

9531 2A Study of the vitamins A, E and C esters penetration into the skin by confocal Raman spectroscopy in vivo [9531-84]

9531 2D Portable widefield imaging device for ICG-detection of the sentinel lymph node. [9531-87]

9531 2E Evaluation of cotton-fabric bleaching using hydrogen peroxide and Blue LED [9531-88]

$95312 \mathrm{~F}$ Analysis of the in vivo confocal Raman spectral variability in human skin [9531-89]

$953121 \quad$ Effects of low level laser in the morphology of the skeletal muscle fiber during compensatory hypertrophy in plantar muscle of rats [9531-92]

$95312 \mathrm{M}$ Confocal Raman study of aging process in diabetes mellitus human voluntaries [9531-96]

$95312 \mathrm{~N}$ Effect of laserphototherapy on human alveolar bone repair: micro tomographic and histomorphometrical analysis [9531-97]

$95312 Z$ Characterization of caries progression on dentin after irradiation with Nd:YAG laser by FTIR spectroscopy and fluorescence imaging [9531-109] 
953132 Automatic analysis of microscopic images of red blood cell aggregates [9531-112]

953135 Thermographic diagnostics to discriminate skin lesions: a clinical study [9531-115]

953137 Fluorescence diagnosis of upper respiratory tract infections [9531-117]

953138 Plasmonic enhancement in the photoinactivation of Escherichia Coli using rose bengal and gold nanoparticles [9531-118]

953139 Fluorescent liposomes to probe how DOTAP lipid concentrations can change red blood cells homeostasis [9531-119]

9531 3A Analysis of photodynamic cream effect in dental caries using optical coherence tomography [9531-120]

9531 3B Micro energy-dispersive $x$-ray fluorescence spectrometry study of dentin coating with nanobiomaterials [9531-121]

9531 3D Assembly and characterization of a fluorescence lifetime spectroscopy system for skin lesions diagnostic [9531-123]

$95313 \mathrm{H} \quad$ The ablation threshold of Er;Cr:YSGG laser radiation in bone tissue [9531-127]

953131 Optical coherence tomography applied to the evaluation of wear of composite resin for posterior teeth [9531-128]

9531 3J Adapting smartphones for low-cost optical medical imaging [9531-129]

9531 3L FT Raman spectroscopy in the study of human teeth under medications demineralization [9531-131]

$95313 \mathrm{~N}$ Effects of infrared laser on the bone repair assessed by $\mathbf{x}$-ray microtomography ( $\mu \mathrm{ct})$ and histomorphometry [9531-133]

953130 New speckle analysis algorithm for flow visualization in optical coherence tomography images [9531-134]

9531 3P New speckle analysis method for optical coherence tomography signal based on autocorrelation [9531-135]

$95313 Q \quad$ Determination of radiation levels without producing damage to blood cells [9531-136]

953135 Comparative analysis of gingival phenotype in animal and human experimental models using optical coherence tomography in a non-invasive approach [9531-139]

$95313 \mathrm{U}$ In situ visualization of dermal collagen dynamics during skin burn healing using secondharmonic-generation microscopy [9531-142]

$95313 \mathrm{~V}$ Optical fluorescence spectroscopy to detect hepatic necrosis after normothermic ischemia: animal model [9531-143]

$95313 X$ Simplified variant of an optical chip to evaluate aggregation of red blood cells [9531-145] 
953140 Comparison between two portable devices for widefield PpIX fluorescence during cervical intraepithelial neoplasia treatment [9531-148]

953142 Identification of atherosclerosis using aminolevulinic gold nanoparticle assay in fecal specimens [9531-150]

953143 Characterization of probe contact effects on diffuse reflectance spectroscopy measurements [9531-151]

953144 UV protection of euglenoids: computation of the electromagnetic response [9531-152]

953146 Time-resolved and steady-state fluorescence spectroscopy for the assessment of skin photoaging process [9531-154]

953147 Study of lumineers' interfaces by means of optical coherence tomography [9531-155]

953148 Diffuse reflectance imaging to predict heterogeneities in turbid optical phantom [9531-156]

953149 Portable fluorescence microendoscope system for smartphones and its applications [9531-157]

9531 4A Onychomycosis diagnosis using fluorescence and infrared imaging systems [9531-158]

9531 4C Preparation and optimization of aminolevulinic acid with gold nanoparticles for photothermal and photodynamic therapies applications [9531-160]

$95314 \mathrm{D}$ Development of automated prototype for studying the effect of solar aging on sunglasses [9531-161]

$95314 \mathrm{E}$ Diffuse reflectance spectroscopy of liver tissue [9531-162]

$95314 \mathrm{G}$ Laser speckle contrast imaging of blood flow from anesthetized mice: correcting drifts in measurements due to breathing movements [9531-165]

$95314 \mathrm{H}$ Examination of the variation of the optical diffusion properties in nanophosphor materials for use in biomedical imaging and instrumentation [9531-166] 


\section{Authors}

Numbers in the index correspond to the last two digits of the six-digit citation identifier (CID) article numbering system used in Proceedings of SPIE. The first four digits reflect the volume number. Base 36 numbering is employed for the last two digits and indicates the order of articles within the volume. Numbers start with 00, 01, 02, 03, 04, 05, 06, 07, 08, 09, 0A, 0B...0Z, followed by 10-1Z, 20-2Z, etc.

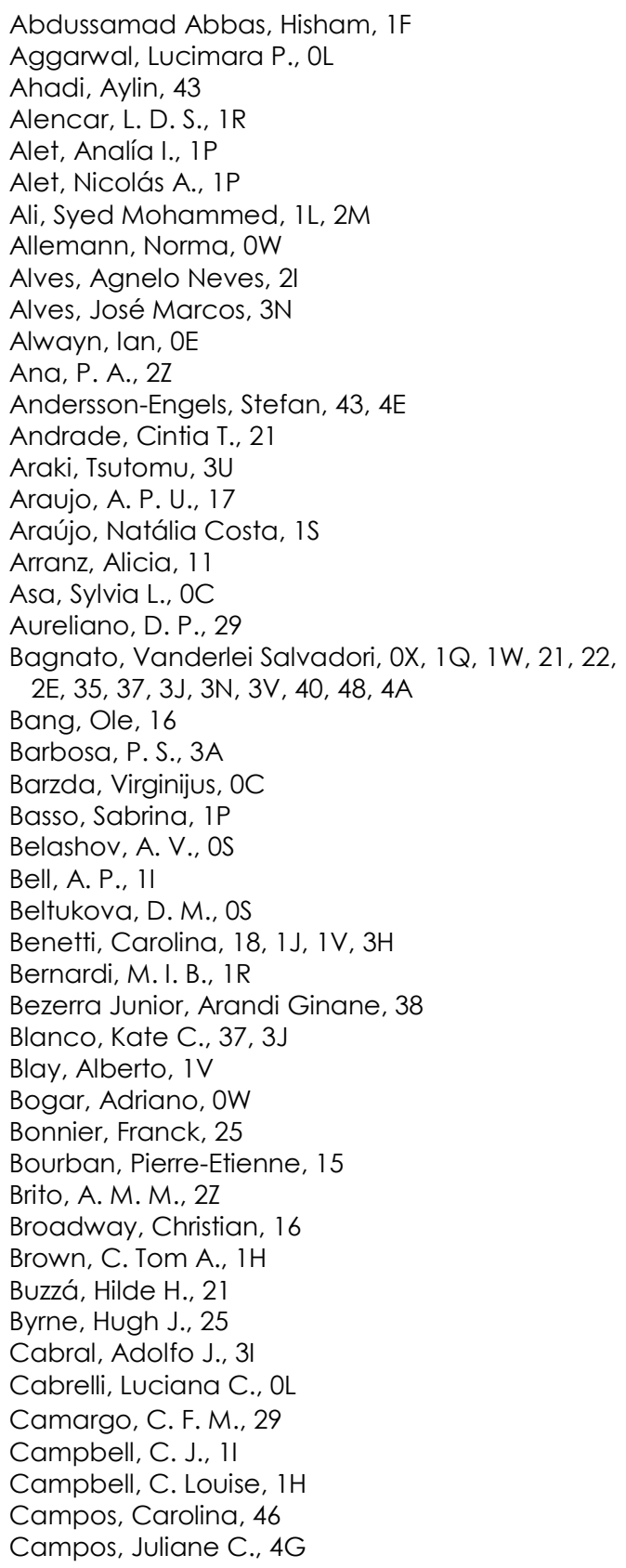

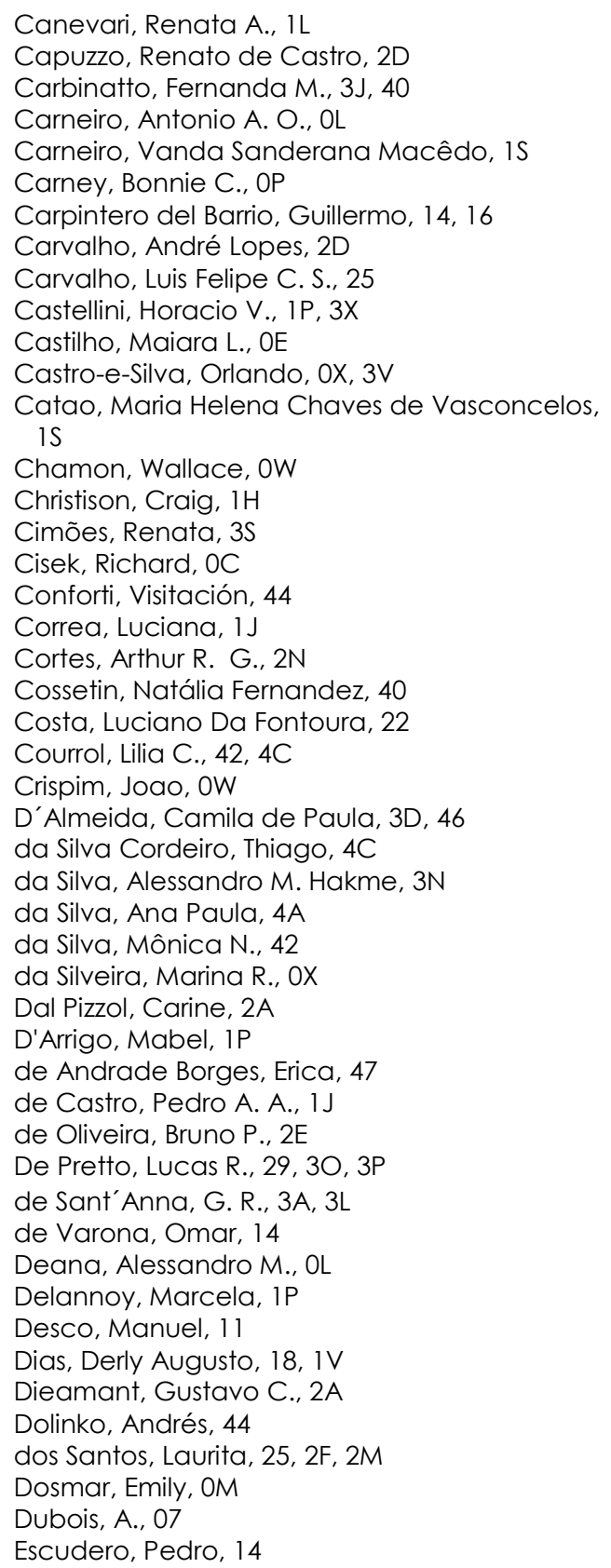


Espirito Santo, A. M., 3L

Farahi, Salma, OA

Fashir, Samia A., OE

Fávero, Priscila Pereira, 1L, 2M

Feitosa, Daniela S., 35

Fernandes Cassimiro-Silva, Patrícia, 47

Fernandes, Kristianne Porta Santos, 21

Fernandez, Jorge L., 3V

Ferreira, Julio C. B., 4G

Flint, Stephen, 25

Florez, Fernando L. E., 1Q, $1 T$

Fontes, Adriana, 39

Fortunato, Thereza Cury, 48, 4A

Freitas, Anderson Z., 29, 3A, 3O, 3P

Fresno, Manuel, 11

Fukushima, Shu-ichiro, 3U

Gallego, Daniel, 16

Gerbi, Marleny Elizabeth Martinez, is

Golaraei, Ahmad, OC

Gomes, L. M., 4D

Gómez-García, Pablo Aurelio, 1 1, 2D, 49

Gonçalves, Karina de O., 42, 4C

Goulart, Viviane P., 1J

Govone, Angelo Biasi, 2D

Grancianinov, Karen J. S., 2F

Grandi, Natália D. P., IT

Grecco, Clovis, 1Q, 1T, 21

Guerra, Bruna A., 31

Guimarães, F. E. G., 17

Guthrie, Micah J., OM

Harrison, D. J., 11

Hase, Eiji, $3 \mathrm{U}$

Hewitt, Kevin C., OE

Higa, A. G., 3L

Hoffman, Hilary A., OP

Hones, Logan, OM

Horliana, Anna C. R. T., 2N

Humme, Julia Honselmann Genannt, 38

Hupman, Michael A., OE

Inada, Natalia Mayumi, 37, 3J, 40, 4A

Inchaussandague, Marina E., 44

Isensee, Debora, 2A

Jamieson, L. E., 11

Kagel, Heike, 38

Kalil, Sandra, 21

Kandarakis, I., 4H

Kang-Mieler, Jennifer J., OM

Khoushabi, Azadeh, 15

Krouglov, Serguei, OC

Kurachi, Cristina, OB, OX, 22, 2D, 35, 37, 3D, 3J, 3V,

$40,46,48,49,4 \mathrm{~A}$

Lamela Rivera, Horacio, 14, 16

Larese, Mónica G., 32

Lascala, Cesar A., 2N

Lee, Christopher L. D., OE

Leggio, Luca, 14

Leônidas Gomes, Anderson Stevens, 3I, 3S, 47

Liaparinos, P., 4H

Lima, Cassio A., $1 \mathrm{~J}$

Lima, F. W. S., 1R
Lins, E. C. C. C., $2 Z$

Lizarelli, Rosane F. Z., 1Q, 1T, IW

Lobo, Anderson de Oliveira, 3B

Loew, Murray H., OP

Lombardi, Welington, 40

Lopes, Luciana A., $1 T$

Lyng, Fiona M., 25

Machado, Brena S. A., 31

Magalhães, Daniel Varela, 2D

Mahmood, Umar, 11

Maldonado, Edison Puig, $1 \mathrm{~A}$

Marciano, Fernanda Roberta, 3B

Marques, Márcia M., 2N

Martin, Airton A., 1L, 25, 2A, 2F, 2M, 3L

Martinello, Valeska C. A., 2A

Martínez Ortega, Lisbeth L., 3Q

Matos, Anna L. L., 39

Mayjonade, Mallory, 43

Melo, C. A. S., 1 R

Melo, Luciana S. A., 35

Mendes, Fausto Medeiros, 1A

Menezes, Priscila F. C., IW

Menezes, Rebeca Ferraz, is

Menichini, Pablo A., 32

Mesquita Ferrari, Raquel Agnelli, 2l

Mieler, William F., OM

Moffatt, Lauren T., OP

Mogilevych, Borys, 2A, 2F

Morales-Delgado, Edgar E., OA

Moreira, H. H. T., 17

Moreira, Maria S., 2N

Moriyama, Lilian Tan, 2E, 35, 48

Moseley, Harry, $1 \mathrm{H}$

Moser, Christophe, OA, 15

Mota, Cláudia C. B. O., 31, 3S

Nahorny, Sídnei, 3B

Nascimento, E. B., 3L

Navab, Roya, OC

Neto, Jarbas C. C., OW

Neto, Lazaro P. M., 1L, 25

Nilsson, Jan, 4E

Niu, Carolyn, OC

Nogueira, Gesse E. C., 3O, 3P, 4G

O'Callaghan, Kate, 25

Osiński, Marek, 14

Osório Fernandes, Luana, 3S, 47

Osswald, Christian R., OM

O'Sullivan, Jeff, 25

Paolillo, Alessandra Rossi, 3N

Paolillo, Fernanda Rossi, 3N

Papadopoulos, loannis N., OA

Pratavieira, Sebastião, OB, 21, 22, 3D, 3J, 3V, 46,

49

Parra Orjuela, C. Nataly, $3 Q$

Pavan, Theo. Z., OL

Pelissari, Pedro I. B. G. B., OL

Pereira, Goreti, 39

Pereira, Liliane, 1L, 2M

Petrov, N. V., OS

Pincus, S. H., 17 
Pioletti, Dominique P., 15

Pizzo, Renata C. A., 1Q

Politano, Rodolfo, 18

Pospori, Andreas, 16

Prindeze, Nicholas J., OP

Psaltis, Demetri, OA

Quinto, Jose, Jr., IV

Quiroga Bautista, J. Manuel, $3 Q$

Rangel, Joao L., 2A, 2F

Raniero, Leandro J., OE

Reiff, Rodrigo Bezerra de Menezes, 3N

Reistad, Nina, 43, 4E

Requena, Michelle B., IW

Ribeiro, M. S., 29

Ribeiro, Márcio A. C., 4G

Ripoll, Jorge, 11

Riquelme, Bibiana D., 1P, 32, 3X

Rocha-Cabral, Renata Maciel, 1 A

Romano, Renan A., 3V

Romão, Marcia M. A., 2N

Rosa, Edvaldo Antonio Ribeiro, 38

Sadraeian, M., 17

Saito Nogueira, Marcelo, 3D, 46

Sakashita, Shingo, OC

Salvio, Ana Gabriela, 22, 35

Samad, Ricardo E., 4C

Sankarankutty, Ajith K., 3V

Santos, Beate S., 39

Santos, E. A. P., 3L

Sbrissa, David, 22

Schizas, Constantin, 15

Schmocker, Andreas M., 15

Semenova, I. V., OS

Shupp, Jeffrey W., OP

Silva, C. R., 29

Silva, F. M. L., IR

Silva, Flávia de Oliveira, 4C

Sinha, Lagnojita, OM

Skigin, Diana C., 44

Soares, Luís Eduardo Silva, 3B

Sousa, Mariane P., 2F

Speciali, Jose G., $1 Q$

St. Lawrence, Keith, OM

Stringasci, Mirian Denise, 21, 35, 4A

Sturesson, Christian, 4E

Sugden, Kate, 16

Tanaka, Ryosuke, 3U

Teixeira Rosa, Ramon Gabriel, OB, 3D, 49

Téllez Soto, Claudio Alberto, 1L, 25, 2M

Terena, Stella Maris Lins, 2

Tichaver, Kenneth M., OM

Toderi, Martín A., 3X

Tokarz, Danielle, OC

Tolivia, Analía, 44

Travieso, Gonzalo, 22

Triplett, Gregory, $1 \mathrm{~F}$

Tsao, Ming-Sound, OC

Tsutae, F. M., 17

Tuboy, Aparecida M., 21

Turchiello, Rozane de Fátima, 38
Valencia, Claudio, 44

Valentine, Ronan M., $1 \mathrm{H}$

Vaquero, Juan José, 11

Varoto, Cinthia, 40

Vasyutinskii, O.S., OS

Veloso, Marcelo Noronha, 18

Ventura, L., 4D

Vieira Júnior, Nilson D., 4C

Vilhelmsson Timmermand, Oskar, 4E

Vollet-Filho, José D., 0X, 21, 3J, 3V

Wilson, Brian C., OC

Wood, Kenneth, $1 \mathrm{H}$

Woyessa, Getinet, 16

$\mathrm{Xu}$, Xiaochun, OM

Yasufuku, Kazuhiro, OC

Yasui, Takeshi, 3U

Zamataro, Claudia B., IV

Zanchin, Anderson L., 21

Zanin, Hudson, 3B

Zezell, Denise Maria, 18, 1A, 1J, 1V, 2Z, 3H

Proc. of SPIE Vol. $9531953101-10$ 


\section{Conference Committees}

Conference Chairs

Cristina Kurachi, Universidade de São Paulo (Brazil)

Katarina Svanberg, Lund University Hospital (Sweden)

Bruce J. Tromberg, Beckman Laser Institute and Medical Clinic

(United States)

Conference Co-chair

Vanderlei Salvador Bagnato, Universidade de São Paulo (Brazil)

Conference Program Committee

Lilian Tan Moriyama, Universidade de São Paulo (Brazil)

Natalia Mayumi Inada, Universidade de São Paulo (Brazil)

Sebastião Pratavieira, Universidade de São Paulo (Brazil)

Local Committee

Cristina Kurachi, Universidade de São Paulo (Brazil)

Vanderlei Salvador Bagnato, Universidade de São Paulo (Brazil)

Lilian Tan Moriyama, Universidade de São Paulo (Brazil)

N Sebastião Pratavieira, Universidade de São Paulo (Brazil)

Natalia Mayumi Inada, Universidade de São Paulo (Brazil)

\section{Session Chairs}

Plenary Sessions

Cristina Kurachi, Universidade de São Paulo (Brazil)

1 Tissue Microscopy

Herch Moysés Nussenzveig, Universidade Federal do Rio de Janeiro (Brazil)

2 NanoBiophotonics

Tuan Vo-Dinh, Duke University (United States)

3 Tissue Optics

Stefan Andersson-Engels, Lund University (Sweden)

4 Photodiagnosis

Ifor Samuel, University of St. Andrews (United Kingdom) 
5 Clinical Applications

Cristina Kurachi, Universidade de São Paulo (Brazil)

6 Instrumentation

Airton A. Martin, Universidade do Vale do Paraíba (Brazil)

7 Spectroscopy I

Denise M. Zezell, Universidade de São Paulo (Brazil)

8 Tissue Optics II

Timothy C. Zhu, The University of Pennsylvania Health System (United States)

9 Spectroscopy II

Zhongping Chen, Beckman Laser Institute and Medical Clinic (United States) 


\section{Introduction}

SPIE Biophotonics South America was a joint-meeting with the 15th World Congress of the International Photodynamic Association (IPA) and took place on 23-25 May 2015, at the Belmond Copacabana Palace Hotel, Rio de Janeiro, Brazil. The first edition of the SPIE-BSA conference had 107 registered attendees from 16 nations including: Argentina, Brazil, Canada, Colombia, France, Greece, Japan, Mexico, Switzerland, Denmark, the United Kingdom, Ireland, Sweden, the Russian Federation, Spain, and the United States, contributing with 49 oral and 79 poster presentations. In IPA 2015, 200 participants from 27 nations were registered. Some attendees presented contributions in both conferences. Exciting and new research results were presented on topics related to tissue optics, plasmonic nanosensors, OCT, tissue microscopy, photodiagnosis, spectroscopy, nanobiophotonics, photonic instrumentation, and clinical applications.

The participants from both meetings could attend any of the SPIE and IPA sessions, resulting in a productive interaction. All tutorials, plenary lectures, and poster sessions were SPIE/IPA shared activities.

Cristina Kurachi 